\title{
Financial Performance of Indian Pharmaceutical Companies: Analysis of Leverage and Cost of Capital
}

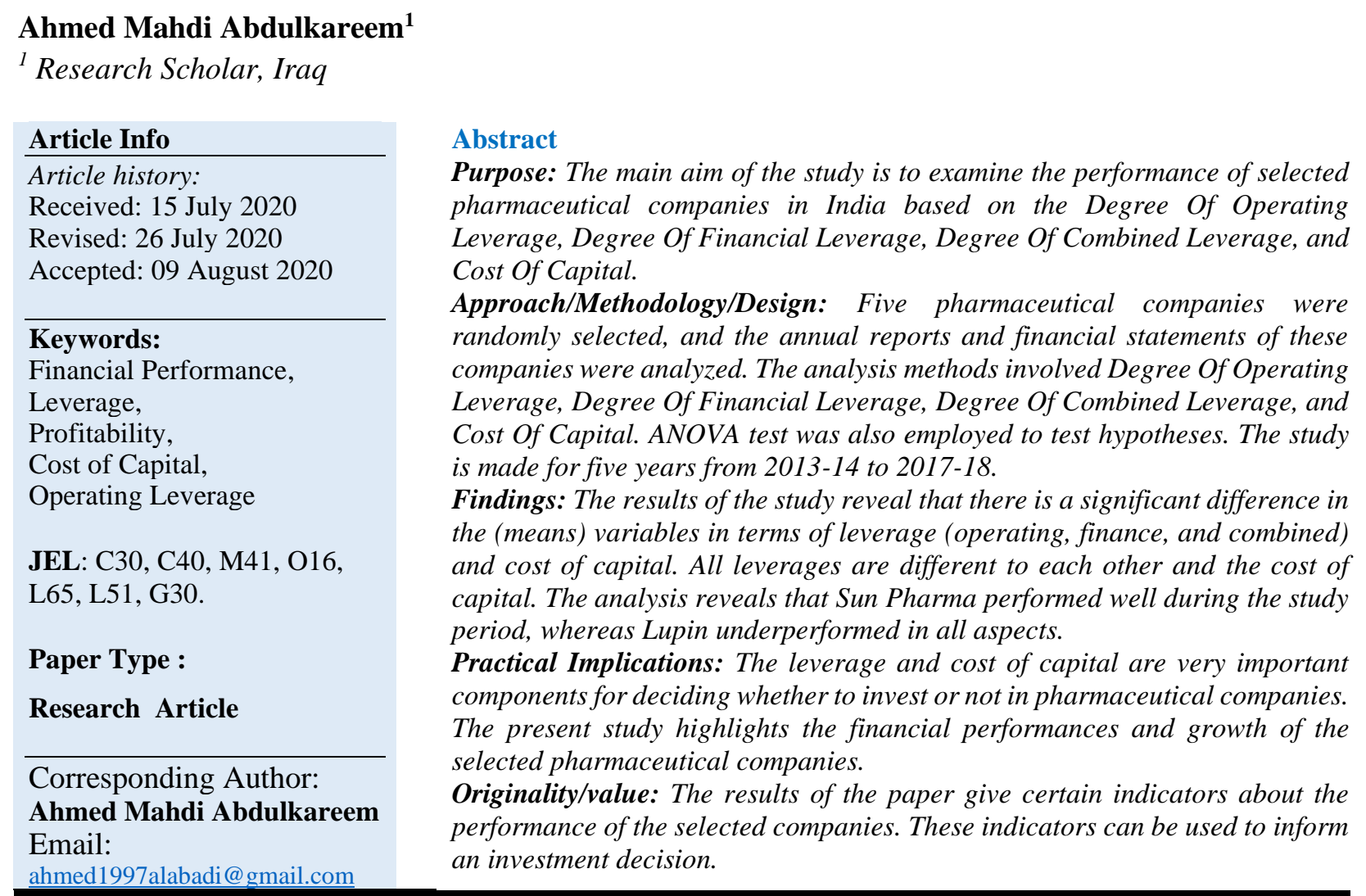

\section{Introduction}

Leverage and cost of capital are the very important components for the evaluation and effective utilization of the equity share. Operating leverage shows the operating cost efficiency of every firm and its fixed cost. Financial leverage is concerned with the rising of the funds from the source for which a firm has to bear fixed charges. It refers to fixed costs like interest expenses and other fixed costs. Financial leverage is directly associated with financial risk. The financial decision taken based on the capital structure provides the proportion of the firm how much debt is used, Equity, Preference share, etc.

The financial leverage is the proportions of the operating profit and profit after tax. The combined leverage is the combination of the operating leverage and financial leverage of the company using debenture in the company and other costs (ICAI.Org, 2018; Sanjeev, 2013; I.M. Panday, 2013).

The proper use of debt financing is one of the major decision areas of corporate financial management (Solomon, 1963). The cost of capital is a very important concept and it is widely used in economics and accounting. It gives investors ideas about a possible opportunity of 
investment. Wise company management will only invest in initiatives and projects that will provide returns that exceed the cost of their capital. In addition, there is a theoretical relationship between systematic risk and the firm's leverage and accounting beta (Bowman, 1979).

Financing decision refers to the selection of appropriate financing-mix and so it relates to the capital structure or leverage. Due to the fact that there is no business without risks, risk management and minimization of its expected cost are one of the urgent tasks of enterprise management (Chiladze, 2019). Leverage refers to the ability of a firm in employing long term funds having a fixed cost, to enhance returns to the owners. In other words, leverage is the amount of debt that a firm uses to finance its assets. The most common measures that are used for financial analysis include (i) Operating Leverage, (ii) Financial Leverage, and (iii) Combined Leverage. The cost of capital is a very important factor to be considered in deciding the firm's capital structure.

Poonam and Muralidhar (2014) conducted a study on two manufacturing companies. The performance of Titan Company Ltd and Timex Indian Group was examined. The study period was from 2008 to 2013. For analyzing data, the researchers employed $t$-test in the micro soft excel sheet. The results of the study reveal that there is a relationship between operating,finance,combined leverage, and EPS (Poonam \& Muralidhar, 2012).

In their study "Leverage Analysis and Corporate Earnings: A Study of Food and Beverage Firms in Nigeria", Kwarbai, Olayinka, \& Ajibade(2016) examined the relationship between age and leverage and the effect on EPS of the manufacturing firm. They used the regression model in which they found that there is a relationship between leverage and cost of capital. Accordingly, the impact of leverage on the cost of capital is positively affected by two variables (Kwarbai, Olayinka, \& Ajibade, 2016). In addition, Mukesh C. Ajmere (2012) in their paper "Leverage Analysis and Its impact on share price and earning of the selected steel companies of India - An empirical study" found relationships between leverage and cost of capital and valuation of the firm. They examined the operating leverage, financial leverage, and cost of capital of the firm and he used One-Way ANOVA test and $t$-test. Their analysis reveals that there is a relationship of two variables (Mukesh, 2012).

This article is an attempt to examine the performance of four pharmaceutical companies in India. The aim is to evaluate their financial performance in the period from 2013-14 to 2017-18. Since financial data of companies is very significant for investment decisions, this study analyzes the annual reports of Sun Pharma, Cipla, Aurobindo Pharma, Lupin, and Dr.Reddy Labs in order to determine their financial performance from 2013 to 2018.

\section{Methodology and Procedures}

The sample of the study only includes five pharmaceutical companies: Sun Pharma, Cipla, Aurobindo Pharma, Lupin, Dr.Reddy Labs. Simple random sampling was used to select the sample from top pharmaceutical companies in India. The study relies largely on secondary 
data that was obtained from the annual reports and financial statements of the selected companies. In addition to the annual reports, different publications have also been used in this study.

The study is made for five years from 2013-14 to 2017-18. The most appropriate parametric and non- parametric tests are used in data analysis. The data obtained is presented through different graphs and tables. Data has been converted in to relative measure such as ratios, percentages, indices rather than the absolute data. The data has been analyzed and hypotheses have been tested at 5\% level of significance, by employing t -test, ANOVA technique, In this study, the used tools for data analysis are Degree Of Operating Leverage, Degree Of Financial Leverage, Degree Of Combined Leverage, and Cost Of Capital.

3. Results and Discussion

Analysis of Degree of Operating Leverage:

$$
\text { Operating Leverage }=\frac{\text { Contribution }}{\text { OperatingProfit(EBIT) }}
$$

Table: 1: Degree of Operating Leverage

\begin{tabular}{|c|c|c|c|c|c|}
\hline Year & $\begin{array}{c}\text { Sun } \\
\text { Pharma }\end{array}$ & Cipla & $\begin{array}{c}\text { Aurobindo } \\
\text { Pharma }\end{array}$ & Lupin & $\begin{array}{c}\text { Dr.Reddy } \\
\text { Labs }\end{array}$ \\
\hline $2013-14$ & 2.00 & 2.00 & 1.70 & 1.55 & 1.77 \\
\hline $2014-15$ & 3.53 & 2.42 & 1.77 & 1.63 & 1.94 \\
\hline $2015-16$ & 4.61 & 2.21 & 1.80 & 1.62 & 2.04 \\
\hline $2016-17$ & 3.54 & 2.50 & 2.20 & 1.56 & 2.34 \\
\hline $2017-18$ & 3.63 & 2.39 & 1.83 & 2.09 & 2.60 \\
\hline Mean & $\mathbf{3 . 4 6}$ & $\mathbf{2 . 3 0}$ & $\mathbf{1 . 8 6}$ & $\mathbf{1 . 6 9}$ & $\mathbf{2 . 1 4}$ \\
\hline Maximum & $\mathbf{4 . 6 1}$ & $\mathbf{2 . 5 0}$ & $\mathbf{2 . 2 0}$ & $\mathbf{2 . 0 9}$ & $\mathbf{2 . 6 0}$ \\
\hline Minimum & $\mathbf{2 . 0 0}$ & $\mathbf{2 . 0 0}$ & $\mathbf{1 . 7 0}$ & $\mathbf{1 . 5 5}$ & $\mathbf{1 . 7 7}$ \\
\hline
\end{tabular}

Sources: Computed from annual report of selected pharmaceutical companies

Chart 1: Degree of Operating Leverage 


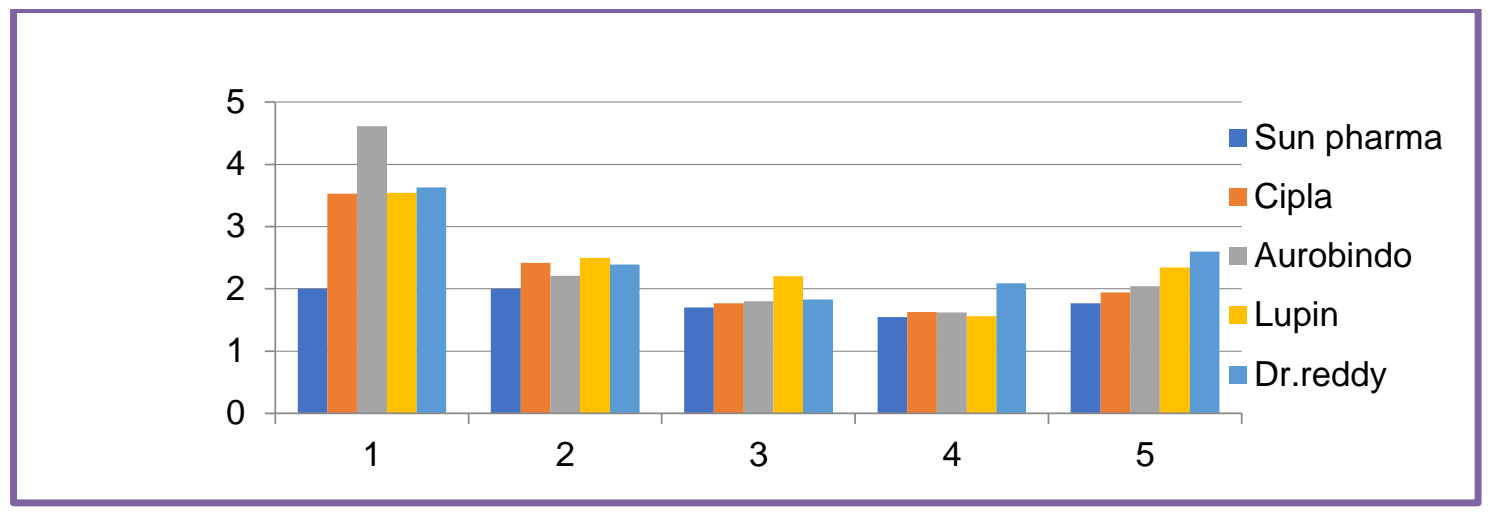

Sources: Computed from annual report of selected pharmaceutical companies

Table no.1 indicates the degree of Operating Leverage of pharmaceutical Companies. The average operating leverage of Sun Pharma is 3.46, for Cipla is 2.30, for Aurobindo Pharma is 1.86, for Lupin is 1.69 , for Dr. Reddy Labs is 2.14 respectively. As per the above table, the highest average is of Sun Pharmaceutical Companies and the lowest average is of Lupin Pharmaceutical Companies in India during the study period.

\section{Hypothesis Testing:}

H0:-There is no significant difference between the Degree of Operating Leverage of selected pharmaceutical companies in India during the study period.

H1:-There is a significant difference between the Degree of Operating Leverage of selected pharmaceutical companies in India during the study period.

Table 2: ANOVA Test

\begin{tabular}{|l|c|c|c|c|c|c|}
\hline Source of Variation & SS & d.f & MS & F & P-value & F crit. \\
\hline Between Groups & 9.708904 & 4 & 2.427226 & 10.90378 & $7.41 \mathrm{E}-05$ & 2.866081 \\
\hline Within Groups & 4.45208 & 20 & 0.222604 & & & \\
\hline Total & $\mathbf{1 4 . 1 6 0 9 4}$ & $\mathbf{2 4}$ & & & & \\
\hline
\end{tabular}

Sources: author

The above ANOVA table indicates that the calculated value of the ANOVA test is 10.9037 and the critical value (table value) of ANOVA is 2.8660 at the $5 \%$ level of significance. The Fcalculated value is more than the table value so that the Null hypothesis is rejected and the alternative hypothesis is accepted. Therefore, it concluded that there is a significant difference between degrees of operating leverage among the selected pharmaceutical companies in India during the study period.

\section{Degree of Financial Leverage}


Formula:- $\quad$ Financialleverage $=\frac{\text { operatingprofit }(\mathrm{EBIT})}{\text { Profitbef oretax }(\mathrm{EBT})}$

Table3: Degree of Financial Leverage

\begin{tabular}{|c|c|c|c|c|c|}
\hline Year & Sun Pharma & Cipla & $\begin{array}{c}\text { Aurobindo } \\
\text { Pharma }\end{array}$ & Lupin & $\begin{array}{c}\text { Dr.Reddy } \\
\text { Labs. }\end{array}$ \\
\hline $2013-14$ & 1.03 & 1.05 & 1.05 & 1.01 & 1.02 \\
\hline $2014-15$ & 1.80 & 1.06 & 1.10 & 1.02 & 1.02 \\
\hline $2015-16$ & 2.44 & 1.05 & 1.01 & 1.01 & 1.01 \\
\hline $2016-17$ & 1.23 & 1.02 & 1.02 & 1.02 & 1.02 \\
\hline $2017-18$ & 1.50 & 1.01 & 1.01 & 1.01 & 1.03 \\
\hline Mean & $\mathbf{1 . 5 9}$ & $\mathbf{1 . 0 3}$ & $\mathbf{1 . 0 3}$ & $\mathbf{1 . 0 1}$ & $\mathbf{1 . 0 2}$ \\
\hline Maximum & $\mathbf{2 . 4 4}$ & $\mathbf{1 . 0 6}$ & $\mathbf{1 . 1 0}$ & $\mathbf{1 . 0 1}$ & $\mathbf{1 . 0 3}$ \\
\hline Minimum & $\mathbf{1 . 0 2}$ & $\mathbf{1 . 0 1}$ & $\mathbf{1 . 0 1}$ & $\mathbf{1 . 0 1}$ & $\mathbf{1 . 0 1}$ \\
\hline
\end{tabular}

Sources: Computed from the annual report of selected pharmaceutical Companies

Above table indicate the degree of financial leverage of all selected pharmaceutical companies in India. The average financial leverage of Sunpharma is 1.59, for Cipla and Aurobindo pharma is 1.038 , and for Lupin is 1.01 , for Dr. Reddy is 1.02 respectively among the study period. Maximum mean of financial leverage in the Companies of sun pharmaceutical Companies in India and minimum financial leverage Lupin pharmaceutical companies in India during the study period.

Chart 2: Degree of Financial Leverage

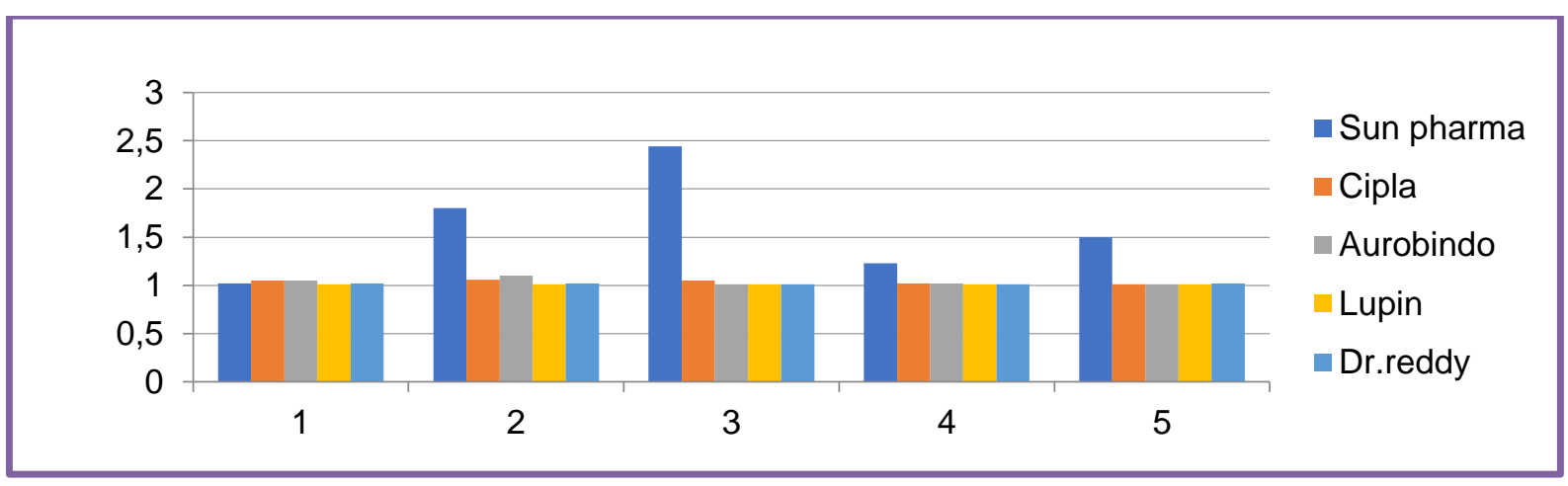

Sources: Computed from annual report of selected pharmaceutical companies

The above table chart presents the maximum \& minimum degree of financial leverage of all selected units. The maximum financial leverage of Sun Pharma is 2.44 in the year 2015-16 and a minimum 1.03 in the year of 2013-14. This financial leverage indicates the relationship between EBIT and EBT. When EBIT increases, financial leverage also increases. 


\section{Hypothesis Testing:}

H0:-There is no significant difference between the Degree of Financial Leverage of selected pharmaceutical companies in India during the study period.

H1:-There is a significant difference between the Degree of Financial Leverage of selected pharmaceutical companies in India during the study period.

Table 4: ANOVA Test- Single Factor

\begin{tabular}{|l|c|c|c|c|c|c|}
\hline Source of Variation & SS & d.f & MS & F & P-value & F crit. \\
\hline Between Groups & 1.31899264 & 4 & 0.329748 & 5.342254 & 0.0043 & 2.866081 \\
\hline Within Groups & 1.2344908 & 20 & 0.061725 & & & \\
\hline Total & $\mathbf{2 . 5 5 3 4 8 3 4 4}$ & $\mathbf{2 4}$ & & & & \\
\hline
\end{tabular}

Source: author

The above ANOVA table indicates that the calculated value of the ANOVA test is 5.3422 and the critical value (table value) of ANOVA is 2.8660 at the $5 \%$ level of significance. The F-calculated value is more than the table value so that the Null hypothesis is rejected and the alternative hypothesis is accepted. Therefore, it is concluded that there is a significant difference between degrees of financial leverage among the selected pharmaceutical companies in India during the study period.

\section{Degree of Combined Leverage:}

Formula:- $\quad$ DCL $=$ DOL $\times$ DFL $=\frac{\% \text { changeinEBIT }}{\% \text { chaneinsales }} \times \frac{\% \text { changeinEPS }}{\% \text { changeinEBIT }}$

Table 5: Degree of Combined Leverage

\begin{tabular}{|c|c|c|c|c|c|}
\hline Year & $\begin{array}{c}\text { Sun } \\
\text { Pharma }\end{array}$ & Cipla & $\begin{array}{c}\text { Aurobindo } \\
\text { Pharma }\end{array}$ & Lupin & $\begin{array}{c}\text { Dr.Reddy } \\
\text { Labs. }\end{array}$ \\
\hline $2013-14$ & 2.04 & 2.10 & 1.80 & 1.56 & 1.80 \\
\hline $2014-15$ & 6.36 & 2.57 & 1.95 & 1.63 & 1.92 \\
\hline $2015-16$ & 11.24 & 2.32 & 1.83 & 1.63 & 2.08 \\
\hline $2016-17$ & 4.35 & 2.55 & 2.25 & 1.58 & 2.38 \\
\hline $2017-18$ & 5.46 & 2.41 & 1.86 & 2.11 & 2.66 \\
\hline Mean & $\mathbf{5 . 8 9}$ & $\mathbf{2 . 3 9}$ & $\mathbf{1 . 4 0}$ & $\mathbf{1 . 7 1}$ & $\mathbf{2 . 1 7}$ \\
\hline
\end{tabular}




\begin{tabular}{|c|c|c|c|c|c|}
\hline Maximum & $\mathbf{1 1 . 2 4}$ & 2.57 & 1.95 & 2.11 & 2.66 \\
\hline Minimum & $\mathbf{2 . 0 4}$ & $\mathbf{2 . 1 0}$ & $\mathbf{1 . 8 0}$ & 1.56 & 1.80 \\
\hline
\end{tabular}

Sources: computed from annual report of selected pharmaceutical companies

The Above table presents the degree of combined leverage of all selected units. The average combined leverage of Sun Pharma is 5.89 and for Cipla, it is 2.39.In addition, the average combined leverage of Aurobindo is 1.39 and 1.71 for Lupin. Finally, it is 2.17 for Dr. Reddy. Here Sun Pharma Ltd average is the highest because in the year 2015-16 the growth is high. Hence, the average of Sun Pharma is the highest during the study period.

Chart 3: Degree of Combined Leverage

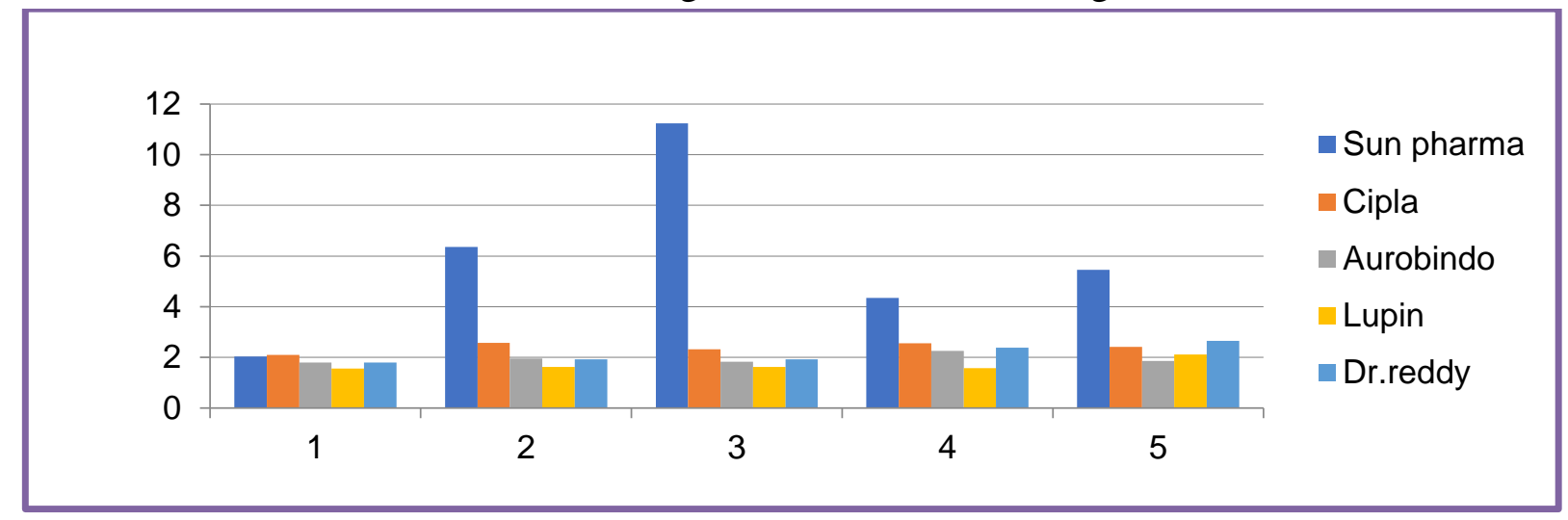

Source: author

The above table shows the different degrees of combined leverage of all selected units. The average combined leverage of Sun Pharma is 5.89 between the years of 2013-14 to 2017-18. The maximum leverage of Sun Pharma is 11.24 in the year of 2015-16. Minimum combined leverage is 2.04 in the year of 2013-14.

Hypothesis:

H0:-There is no significant difference between the Degree of combined Leverage of selected pharmaceutical companies in India during the study period.

H1:-There is a significant difference between the Degree of combined Leverage of selected pharmaceutical companies in India during the study period.

Table 6: ANOVA Table-Single Factor

\begin{tabular}{|l|c|c|c|c|c|c|}
\hline Source of Variation & SS & d.f & MS & F & P-value & F crit. \\
\hline Between Groups & 60.31362 & 4 & 15.078404 & 6.3881 & 0.001759 & 2.866081 \\
\hline Within Groups & 47.20764 & 20 & 2.360382 & & & \\
\hline
\end{tabular}




\begin{tabular}{|l|l|l|l|l|l|l|}
\hline Total & 107.5213 & $\mathbf{2 4}$ & & & & \\
\hline
\end{tabular}

Source: author

The above ANOVA table indicates that the calculated value of the ANOVA test is 5.3334 and the critical value (table value) of ANOVA is 2.8660 at the $5 \%$ level of significance. The F-calculated value is more than the table value so that the Null hypothesis is rejected and the alternative hypothesis is accepted. Therefore it concluded that there is a significant difference between degrees of combined leverage among the selected pharmaceutical companies in India during the study period.

\section{Cost of Capital}

Table 7: Cost of Capital

\begin{tabular}{|c|c|c|c|c|c|}
\hline Year & $\begin{array}{c}\text { Sun } \\
\text { Pharma }\end{array}$ & Cipla & $\begin{array}{c}\text { Aurobindo } \\
\text { Pharma }\end{array}$ & Lupin & $\begin{array}{c}\text { Dr.Reddy } \\
\text { Labs. }\end{array}$ \\
\hline $2013-14$ & $14.77 \%$ & $12.69 \%$ & $13.7 \%$ & $10.7 \%$ & $14.16 \%$ \\
\hline $2014-15$ & $13.91 \%$ & $13.83 \%$ & $14.5 \%$ & $10.9 \%$ & $12.19 \%$ \\
\hline $2015-16$ & $14.46 \%$ & $13.96 \%$ & $13.8 \%$ & $11.20 \%$ & $13.27 \%$ \\
\hline $2016-17$ & $13.10 \%$ & $14.43 \%$ & $14.10 \%$ & $11.9 \%$ & $12.01 \%$ \\
\hline $2017-18$ & $12.66 \%$ & $13.78 \%$ & $15.7 \%$ & $11.2 \%$ & $11.45 \%$ \\
\hline Mean & $\mathbf{1 3 . 7 8 \%}$ & $\mathbf{1 3 . 7 4 \%}$ & $\mathbf{1 4 . 3 6 \%}$ & $\mathbf{1 1 . 1 8 \%}$ & $\mathbf{1 2 . 6 2 \%}$ \\
\hline Maximum & $\mathbf{1 4 . 7 7 \%}$ & $\mathbf{1 4 . 4 3 \%}$ & $\mathbf{1 5 . 7 \%}$ & $\mathbf{1 1 . 9 \%}$ & $\mathbf{1 4 . 1 6 \%}$ \\
\hline Minimum & $\mathbf{1 2 . 6 6 \%}$ & $\mathbf{1 2 . 6 9 \%}$ & $\mathbf{1 3 . 7 \%}$ & $\mathbf{1 0 . 7 \%}$ & $\mathbf{1 1 . 4 5 \%}$ \\
\hline
\end{tabular}

Sources: Computed from annual report of selected pharmaceutical companies

The Above table shows the cost of the capital of selected pharmaceutical companies. The average cost of capital of Sun Pharma Companies is $13.78 \%$, and average cost of capital of Cipla Companies is $13.74 \%$. Moreover, Aurobindo Companies average cost of capital is $14.36 \%$, and average cost of capital of Lupin Companies is $11.18 \%$. For Dr.Reddy Labs, the average cost of capital of is $12.62 \%$. As per the above table, the high cost of capital is $14.36 \%$ for Aurobindo companies and then Sun Pharma Companies. Whenever WACC is less, it indicates a good condition in a company. As per the above table, there is no significant difference in cost of capital among the pharmaceutical companies in India during the study period.

Chart 4: Cost of Capital 


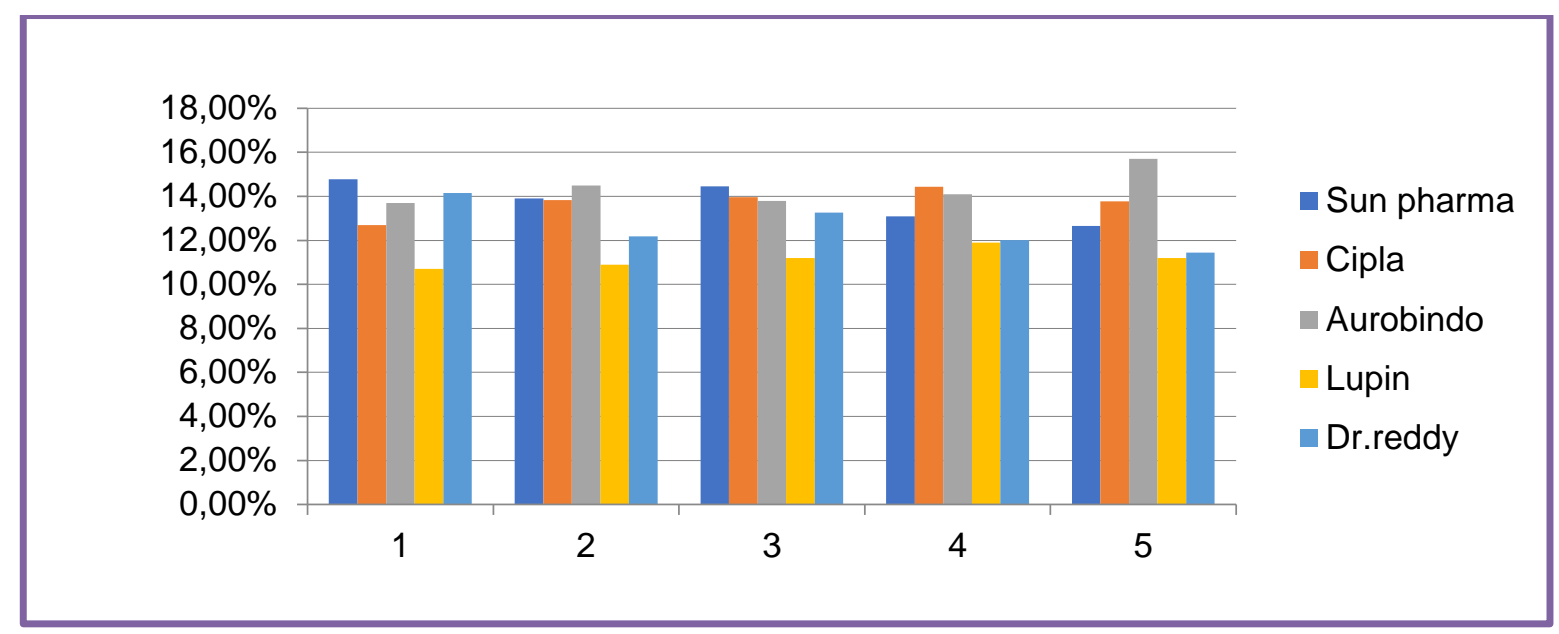

Source: author

The above chart indicates the maximum and minimum cost of capital of all selected pharmaceutical companies. The maximum cost of capital is recorded for Sun Pharma at 14.77\% in the year 2013-14. The high cost of capital is not beneficial for the company because the high cost of capital indicates more than the liability of the company. As per the capital structure theory NI approach, debt is a cheaper source of funds when more debt is used than the cost of capital is reduced. The cost of capital of Cipla minimum is $12.69 \%$ in the year of 2013-14. Other company's cost of capital is shown in the above table.

Hypothesis Testing:

H0:-There is no significant difference between the costs of capital of selected pharmaceutical companies in India during the study period.

H1:-There is a significant difference between the costs of capital of selected pharmaceutical companies in India during the study period.

Table 8: ANOVA Table-Single Factor

\begin{tabular}{|l|c|c|c|c|c|c|}
\hline Source of Variation & SS & d.f & MS & F & P-value & F crit. \\
\hline Between Groups & 0.003186 & 4 & 0.000796 & 12.25995 & $3.37 \mathrm{E}-05$ & 2.866081 \\
\hline Within Groups & 0.001299 & 20 & $6.5 \mathrm{E}-05$ & & & \\
\hline Total & $\mathbf{0 . 0 0 4 4 8 5}$ & $\mathbf{2 4}$ & & & & \\
\hline
\end{tabular}

Source: Author

The above ANOVA table indicates that the calculated value of the ANOVA test is 10.9037 and the critical value (table value) of ANOVA is 2.8660 at the $5 \%$ level of significance. The Fcalculated value is more than the table value so that the Null hypothesis is rejected and the alternative hypothesis is accepted. Therefore, it concluded that there is a significant difference 
between degrees of operating leverage among the selected pharmaceutical companies in India during the study period.

\section{Conclusion and Suggestion}

The present study aimed at measuring the impact of leverage on the cost of capital of selected pharmaceutical companies in India. Five pharmaceutical companies were selected and the annual reports of these companies were analyzed using the degree of operating leverage, degree of financial leverage, degree of combined leverage, and cost of capital. The analysis reveals that the performance of Sun Pharma during the study period was relatively satisfactory, whereas Lupin underperformed in all aspects. In addition, the statistical analysis shows that there is no significant difference in cost of capital among the pharmaceutical companies in India during the study period. As per the data analysis, it is concluded that there is a significant difference between the degrees of combined leverage among the selected pharmaceutical companies in India during the study period.

\section{Conflict of Interest}

The author of the article declares no conflict of interest.

\section{Funding}

This research study was not funded by any institution. The author conducted the study on his own expenses.

\section{References}

Bhayani, S.J., (2006), 'Financial Leverage and Its Impact on Shareholders' Return: A Study of Indian Cement Industry', International Journal of Management Science, 2(1), July, pp. $31-42$.

Solomon, E. (1963). Leverage and the Cost of Capital. The Journal of Finance, Vol. 18, No. 2 (May, 1963), pp. 273-279.

Kwarbai, J. D., \& Ayodeji, A. J. I. B. A. D. E. (2016). Leverage analysis and corporate earnings: A study of food and beverage firms in Nigeria. Journal of Accounting and Financial Management, 2(5), 28-42.

Ajmera, M. (2012). Leverage Analysis and It ${ }^{\text {ee }}$ s Impect on Share Price and Earning of the Selected Steel Companies of India-An Emperical Study. International Journal of Research in Commerce \& Management 3 (7), 129-135.

Chiladze, I. (2019). Factoral Analysis of the Financial Leverage of the Enterprise. Applied Finance and Accounting, 5(1), 42-48.

Bowman, Robert G.(1979). The Theoretical Relationship between Systematic Risk and Financial (Accounting) Variables. The Journal of Finance, Vol. 34, No. 3, pp. 617-630. 